\title{
Gender-Responsive Participatory Variety Selection in Kenya: Implications for Common Bean (Phaseolus vulgaris L.) Breeding in Kenya
}

\author{
Eileen Bogweh Nchanji ${ }^{1, *} \mathbb{\infty}$, Cosmas Kweyu Lutomia ${ }^{2}$, Odhiambo Collins Ageyo ${ }^{1}\left(\mathbb{D}\right.$, David Karanja ${ }^{2}(\mathbb{D}$ \\ and Eliezah Kamau ${ }^{2}$ \\ International Centre for Tropical Agriculture, Nairobi 00621, Kenya; collinsaraf@gmail.com \\ 2 Kenya Agricultural and Livestock Research Organization, Nairobi 00200, Kenya; \\ mascos05@gmail.com (C.K.L.); karanjadr@yahoo.com (D.K.); eliezahngware@yahoo.com (E.K.) \\ * Correspondence: e.nchanji@cgiar.org
}

check for updates

Citation: Nchanji, E.B.; Lutomia, C.K.; Ageyo, O.C.; Karanja, D.; Kamau, E. Gender-Responsive Participatory Variety Selection in Kenya: Implications for Common Bean (Phaseolus vulgaris L.) Breeding in Kenya. Sustainability 2021, 13, 13164. https://doi.org/10.3390/ su132313164

Academic Editor: Marco Lauteri

Received: 16 October 2021

Accepted: 23 November 2021

Published: 27 November 2021

Publisher's Note: MDPI stays neutral with regard to jurisdictional claims in published maps and institutional affiliations.

Copyright: (c) 2021 by the authors. Licensee MDPI, Basel, Switzerland. This article is an open access article distributed under the terms and conditions of the Creative Commons Attribution (CC BY) license (https:/ / creativecommons.org/licenses/by/ $4.0 /)$.

\begin{abstract}
Participatory variety selection (PVS) is the selection of new varieties among fixed lines by farmers under different target environments. It is increasingly being used to select and promote new crop breeding materials in most African countries. A gender-responsive PVS tool was piloted in Embu and Nakuru in the first and second cropping seasons of 2019 to understand similarities and differences between men's and women's varietal and trait preferences for biofortified released varieties and local bean varieties (landraces). Pooled results indicate that varietal and trait preferences between men and women farmers were slightly different but followed gendered roles and division of labor. Women farmers have a higher preference for landraces compared to men due to their availability, affordability and accessibility. Preferences for bean varieties differed between men and women across the two counties. High yielding was the most prioritized trait by both men and women for Mwitemania, Nyota, and Angaza. The findings support the long-held assumption that men prefer market-oriented traits, but women have a greater range of concerns thus less market oriented than men. For Nyota, men's preferences were shaped by market traits, while women's preferences were based on the variety being early maturing, resistant to pests and diseases, marketable, and fast cooking. For other varieties, men preferred Mwitemania because it is high yielding, early maturing, resistant to pests and diseases, and marketable. In contrast, women preferred Mwitemania because of seed availability, fast cooking, and early maturing. However, men's and women's varietal preferences for Angaza were similar, with them reporting early maturing, resistance to pests and diseases, and marketability as attractive traits. Sociodemographic characteristics such as education, age, marital status, and land ownership underlined the differences in trait preferences. Despite having attractive traits for both men and women, Nyota increased drudgery, displaced women from their usual activities, and required additional inputs by women, signaling possible adoption tradeoffs. However, Nyota, Angaza, and Mwitemania can provide the opportunity to increase employment for women. This study calls for gender integration at the design stage of any breeding system to ensure men and women farmers have access to varieties they prefer for food and income generation.
\end{abstract}

Keywords: participatory variety selection; common bean; traits; preferences; benefits; gender; plant breeding

\section{Introduction}

Adoption of new innovations and technologies by farmers in sub-Saharan Africa is considered as one of the solutions to addressing multiple challenges in the region, including the high prevalence of food insecurity and malnutrition [1], poverty [2], adverse effects of climate change [3,4] natural resource depletion and degradation [5], and low agricultural productivity [6]. Nonetheless, technology development, diffusion, and adoption are complex processes and not straightforward. Like many other processes of change and 
rural transformation, technology diffusion and adoption are embedded in demographic, socio-cultural, political, economic, and global dynamics that influence their success [7]. Thus, it is always important to situate technology policy frameworks to address the mentioned challenges within the context of local, national, regional, and global environments. A fundamental step in addressing the challenges is embracing developments in plant breeding which produces some big wins for improving food security in sub-Saharan Africa in the face of poverty and climate change [8]. Eriksson et al. [9], for instance, indicates that plant breeding has played a crucial role in closing yield gaps of ten most important food staples (maize, pearl, sorghum, rice, millet, common bean, cassava, cowpea, banana, sweet potato, and yam) in sub-Saharan Africa in the last two decades through the development of high-yielding, early maturing, drought-tolerant, and pest and disease-resistant varieties.

Breeders do not systematically consider gender-differentiated traits in breeding programs, and when they do, it is still limited [10]. Moreover, breeders find it challenging to develop varieties with traits for diverse users and uses [11]. Thus, it might be better to combine the traits that women and men prefer in most cases [12].

The novelty of this study is comparing gender trait preferences and how they are shaped by socio-economic considerations. It also assesses the implications of the traits on women. However, gender inequality is holding back development in sub-Saharan Africa, where socio-economic considerations are not adequately emphasized during the breeding process. For instance, common bean in Kenya is an important crop where gender inequality in adopting new plant varieties has been observed. Breeders need to know their customers in order to develop varieties that meet their needs and preferences. In addition, they also need to know if gender inequality is likely to hold back the adoption of new varieties. Understanding trait preferences is important for breeders, but there are major knowledge gaps about whether it makes sense to disaggregate beyond gender or other farmer characteristics to understand preferences fully.

Participatory Varietal Selection (PVS) methods commonly in use have several shortcomings. PVS is mainly used in the late stages of a breeding cycle for pre-release screening of advanced lines as a check on their acceptability to producers and other end users. This use of PVS is not primarily oriented to providing feedback to the design of varieties and does not aim to understand farmers' preferences by relating preferences to their individual characteristics (such as gender and education) or their socio-economic resources. As noted by [13], data on farmers' varietal and trait preferences is only valuable if correlated with landholding, household size, sex, and age of the respondent through choice experiments. Burridge et al. [14] also investigated the role of integration of social science research into a breeding pipeline and found evidence that gender mattered in farmers' preferences for common bean varieties in Mozambique. The differences in men and women trait preferences for common bean varieties were shaped by intra-household dynamics. Burridge et al. [14] also found that gender preferences and the ultimate adoption decision by men and women depended on individual, household, farm, and community characteristics. However, Refs. $[13,14]$ did not elaborate on the gender gaps associated with the farmers' trait preferences, which this study aimed to address. This paper seeks to address this knowledge gap by comparing trait and varietal preferences of men and women farmers and relating preferences to their socio-economic characteristics.

Notwithstanding, plant breeding in sub-Saharan Africa faces unique challenges compared with other regions. First, the few products that have been developed have low probability of achieving the targeted outcomes [15]. As breeding programs are underfunded and affected by temporal variability, biotic and abiotic constraints, and spatial variability. Of paramount concern is the structure of farming systems in the region that is dominated by smallholder farmers with striking diversity [15]. The subsistence nature of farming and the less market-oriented breeding programs for most food staples punctuate the differences in preferences for breeding products [16,17], as cited by Lynam [15], postulated that production and marketing considerations and risk as perceived by farmers make them maintain a portfolio of products that do not necessarily meet production and 
consumption objectives or realize the expected returns of plant breeding products. In other words, socio-economic considerations rarely captured in breeding may inhibit the adoption of productivity and consumption-enhancing technologies.

In sub-Saharan Africa, it takes an average of 20 years for plant varieties to move from initial breeding to adoption [18]. Shortening this time calls for the development of farmer-preferred varieties that can only adapt to diverse agro-ecological conditions and meet multiple objectives of targeted customers. But this can be achieved if smallholder farmers are involved in breeding cycles. For this reason, participatory variety selection (PVS) was devised to capture farmer preferred traits in the development of plant breeding products. PVS involves the use of men's and women farmers' information in the selection of promising plant varieties for release. This approach appreciates the fact that men and women farmers may not adopt varieties that are pre-selected for them by breeders, extension workers, or research partners [19]. Additionally, PVS acknowledges that men and women farmers may have different priorities from breeders', and the priorities may shape their preferences and adoption decisions. PVS also acknowledges that selection should be responsive to the needs of men and women farmers in different agro-ecological zones [19].

While trait and product preferences for breeding products may differ and can be captured using PVS tools, men and women farmers work under different socio-economic conditions that might shape their trait preferences [11]. Despite PVS tools providing critical information that enables the definition of market-preferred product profiles, data on the socio-economic environment where men and women operate, and gender issues are not captured conclusively and adequately, even though it has the possibility to shape their trait preferences. To address this gap, we incorporated socio-economic factors, including land ownership and access, education, household headship, age, and marital status of farmers that participate in the standard PVS tool to determine how farmers' bean variety and trait preferences relate to gender and socio-economic background, as well the implications of preferred traits on gender gaps.

The rest of the article proceeds as follows: the second section describes the study's methodological approach and evolution of participatory variety selection and innovative PVS tool; the third section presents the study results and discussion of the finding. The last section provides a conclusion and recommendation based on the results and discussion.

\section{Materials and Methods}

\subsection{Study Location}

This study was conducted in Nakuru and Embu Counties of Kenya, shown in Figure 1. Embu County is located $120 \mathrm{~km}$ North East of Nairobi and covers $2818 \mathrm{~km}^{2}$. Nakuru, called the 'farmers capital' of Kenya, is famous for its agro-based industries. It has an area of $2325.8 \mathrm{~km}^{2}$, with $70 \%$ of it being arable land. In both counties, agriculture is the lifeline, with common bean being one of the leading food crops. The crop is planted twice per year, in the long rainy season (March-May) and short-season (October-December). The average smallholder landholding in the two counties is 0.5 to 1 ha. Moreover, agricultural production is diverse, with both crop and livestock keeping as dominant farm enterprises. 


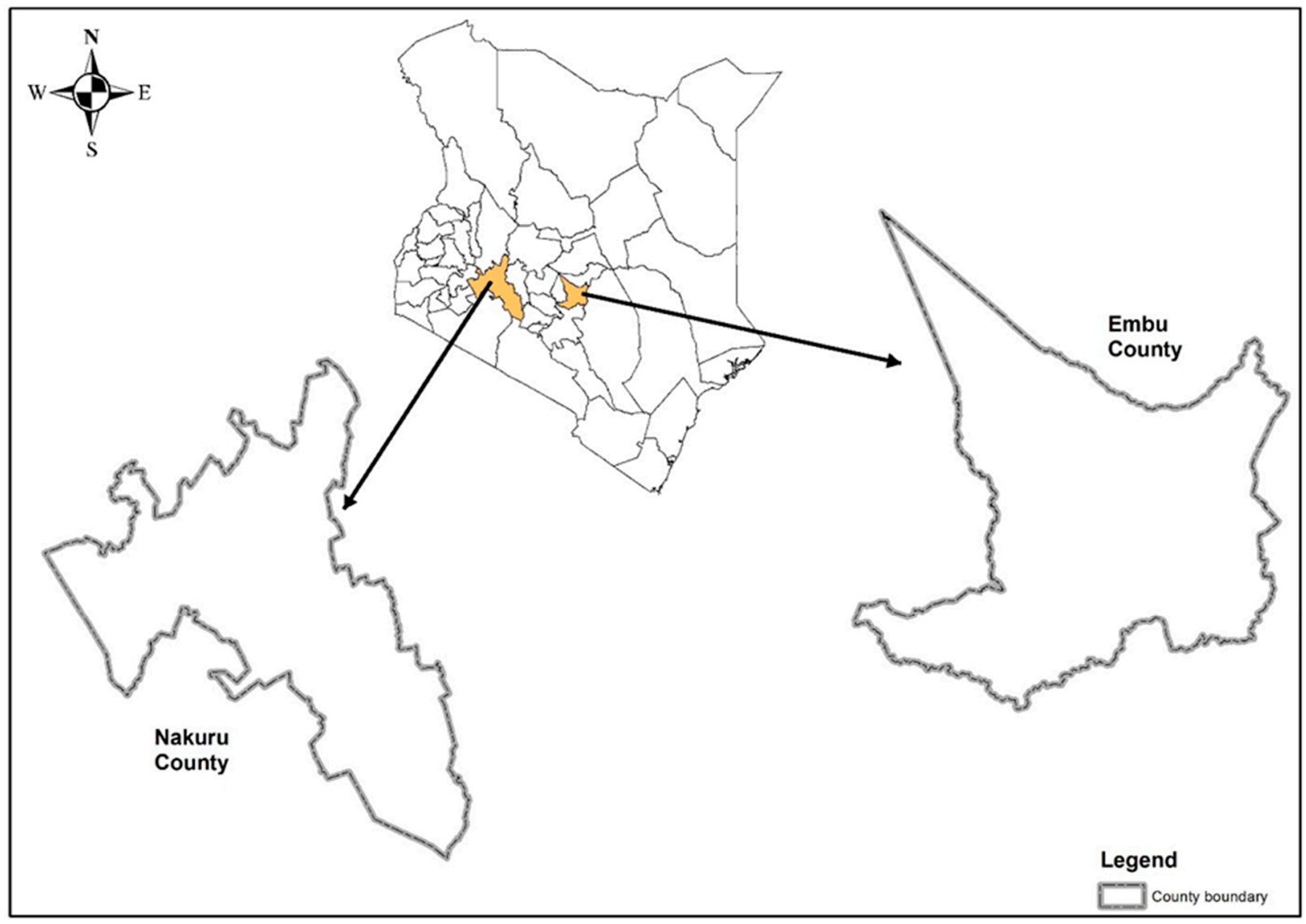

Figure 1. Map of the study area.

\subsection{Evolution of the PVS Tool and Methodological Innovation of the Tool}

When PVS was applied to common bean in Rwanda in the 1990's it involved breeders and farmers, many of them women, in evaluating crop trial lines on-station and on-farm, but at this time, PVS did not contain an explicit gender component [20]. PVS was designed to be done at different stages of maturity of a crop and to include post-harvest, processing, preparation, and tasting but has over time become simplified into a way of getting farmers' options at harvest time. PVS was designed to be used early in the breeding cycle, on-station in breeders' nurseries with many diverse and contrasting accessions. It was intended to rely on open-ended evaluation to elicit the criteria (including trait preferences) that farmers used to judge performance and acceptability.

However, over time, PVS has moved away from open-ended evaluation and focused on involving farmers in selection of preferred varieties and ranking a set of varieties that have been pre-selected, narrowing the range of choice and the purpose of the evaluations with farmers. For instance, a PVS study by [21] determined farmers' selection criteria of sorghum varieties and compared them to breeders' standard practices and agronomic observation with the intention of determining how the selection criteria can be integrated at the early stages of the breeding cycle. The article reports that farmers' definitions of preferred traits were more multivariate than the formal criteria used by breeders to prioritize the same varieties. Farmer preferences are often documented without collecting socio-economic data on the respondents. The approach involves inviting farmers to evaluate a limited number of lines at the final or nearly final stages of the products during on-farm trials or demonstrations [22]. PVS is thus a valuable tool crucial in encouraging and accelerating the diffusion and adoption of nearly released and released varieties [23,24].

According to [25], the use of PVS at the tail-end of the breeding cycle defeats the entire rationale for participatory market-driven research. Because the tool does not capture farmers' preferences beyond age and sex, farmers may evaluate bean varieties as having 
superior traits such as high-yielding, drought tolerance, and pest and disease-resistant but still do not adopt because of the gendered implications of the traits. For instance, highyielding varieties may increase drudgery, displace women from other activities, require additional inputs out of women's reach, or reduce their control over benefits from growing these bean varieties. These observations mean that superior traits do not automatically influence farmers' adoption of the varieties. Besides not going beyond the sex of farmers participating in the evaluation of bean varieties, PVS does not disentangle gender gaps that may explain differences in female farmers' adoption of released varieties.

Notwithstanding, there were differences in how women and men rated the traits, especially with respect to grain quality traits. Therefore, the selection of PVS participants who represent the target end-users or customers has lost profile as a critical step in the methodology - with the entire focus on ways of getting farmers' opinions but glossing over the issue of "whose opinion" and the diversity of views due to social differences and gender. Tegbaru et al. [26] identified gender-differentiated varietal and trait preferences by maize farmers in Mali, Benin, and Nigeria. Men's and women's varietal and trait preferences for drought-tolerant maize varieties differed, suggesting that plant breeding should develop consumer-based traits, considering their characteristics and environments they operate in order to facilitate uptake of new varieties. Tegbaru et al. [26] emphasized that breeding programs should link specific needs and post-harvest processing implications of the traits to trait preferences of men and women farmers. This reality has received limited attention and attempts to link breeding traits to preferences to what men and women need tend to focus on agronomic and market characteristics, ignoring the gendered implications of the targeted traits. Our approach in this paper affirms the position taken by [26] by focusing on the implication of men and women trait preferred on drudgery, the need for additional input by women, displacement of women usual activities, women employment, and control over benefits that accrue from planting their preferred bean varieties.

Considering the PVS shortcoming, the gender specialist at the Alliance of Bioversity International and the International Center for Tropical Agriculture (CIAT) contacted two KALRO breeders to develop a gender responsive PVS tool that combines gender gaps questions, and socio-economic variables to the standard PVS tool. The discussion was based on the possible integration of gender into the recently published G+ Tools developed by the Gender and breeding Initiative team [27-29]. The G+ (customer and product profiling) tools were developed to reorient breeders' attention to farmers' preferences at the stage of variety design and specifically when trait prioritization is decided [30]. G+ Tools are decision-support tools that provide an integrated, systematic and evidence-based protocol for breeding new crop varieties.

The gender gap questions were derived from the "do no harm" and positive benefits of the G+ product profile tool. The "do no harm" flag any negative gender impacts that breeding programs will want to avoid and the positive benefits that a breeding program may include in its objectives. The questions focus on drudgery, displacement of women from their usual activities, employment, additional input requirements, quality, and quantity of bean products under women's control, and women's control over benefits derived from the trait they selected added to the original PVS tool. These questions were asked to men and women farmers in relation to the best traits they selected. In addition, socio-economic variables including age, sex, land size holding, education, land ownership, marital status, source of seed, etc., were also added. Breeding that relies on feedback from the modified PVS tool known as the gender responsive PVS tool would provide information for more inclusive, gender-equitable, and accurate product profiles.

\subsection{Sampling Methods and Data Collection}

Data were collected between May and December 2019 from 93 farmers: 40 in Embu (26 women and 14 men) and 53 in Nakuru (21 women and 32 men). Farmers were invited to attend on-farm bean varieties demonstrations. Using systematic random sampling procedures, county extension officers selected participants from lists provided by different 
farmer groups. The extension officers were encouraged to invite more women than men to achieve increased women's participation since previous PVS studies were male dominated. Another reason why more women were invited was that women dominate bean production in Kenya, with more than $60 \%$ involved in bean production.

Following Teeken et al. [31], we used descriptive statistics to explore the data's salient patterns. Descriptive statistics such as mean, frequencies, and percentages were used to highlight how varietal and trait preferences compared by sex, age, education, land size, and county, etc. The analytical approach provided an easy way of visualizing and tabulating the differences in the distribution of responses.

\section{Results and Discussion}

\subsection{Demographic Characteristics}

The analysis results in Table 1 are sociodemographic and farm characteristics of respondents that participated in this study. Over $80 \%$ of men and women who participated in the study were over 35 years, suggesting low participation of young people in bean production and agriculture in general. Even though questions were asked to individual men and women farmers, we also asked them if they were the household head. The definition of household head was a person making the most decisions about bean production, notwithstanding other farm decisions. The analysis in Table 1 shows that both men and women tended to indicate that they made bean farming decisions. Most (47\%) respondents had primary education, while $40 \%$ had secondary education, suggesting that literacy levels are adequate for acquiring farming information and knowledge by both men and women. More men (91\%) than women (79\%) reported that they were married. Marital status is an important social issue that may accentuate or attenuate gender gaps in terms of decision making, access and control over resources and benefits, time availability for farming activities, and agricultural training and extension.

Table 1. Sociodemographic and farm characteristics of respondents by county and gender.

\begin{tabular}{|c|c|c|c|c|c|c|}
\hline \multirow[b]{2}{*}{ Variable } & \multicolumn{2}{|c|}{ Pooled $(\mathrm{N}=93)$} & \multicolumn{2}{|c|}{ Embu $(N=40)$} & \multicolumn{2}{|c|}{ Nakuru $(\mathrm{N}=53)$} \\
\hline & Women & Men & Women & Men & Women & Men \\
\hline Percent aged 35 years and older & 87.23 & 84.78 & 84.62 & 78.57 & 90.48 & 87.5 \\
\hline Percent of female-headed $\mathrm{HH}$ & 82.61 & 10.87 & 88.46 & 28.57 & 75.00 & 3.13 \\
\hline Percent of male-headed $\mathrm{HH}$ & 17.39 & 89.13 & 11.54 & 71.43 & 25.00 & 96.88 \\
\hline \multicolumn{7}{|l|}{ Educational attainment (\%) } \\
\hline No formal education & 4.26 & 0.00 & 7.69 & 0.00 & & \\
\hline Primary & 48.94 & 45.65 & 34.62 & 28.57 & 66.67 & 53.13 \\
\hline Secondary & 38.30 & 41.30 & 50.00 & 50.00 & 23.81 & 37.5 \\
\hline Tertiary & 8.51 & 8.70 & 7.69 & 14.29 & 9.52 & 6.25 \\
\hline University & 0.00 & 4.35 & 0.00 & 7.14 & 0.00 & 3.13 \\
\hline \multicolumn{7}{|l|}{ Marital status (\%) } \\
\hline Married & 78.72 & 91.3 & 73.08 & 92.86 & 85.71 & 90.63 \\
\hline Single & 4.26 & 4.35 & 7.69 & 7.14 & 0.00 & 3.13 \\
\hline Separated/divorced & 2.13 & 4.35 & 3.85 & 0.00 & 0.00 & 6.25 \\
\hline Widowed & 14.89 & 0 & 15.38 & 0.00 & 14.29 & 0.00 \\
\hline \multirow[t]{2}{*}{ Average total land size } & 1.06 & 1.23 & 1.02 & 0.91 & 1.11 & 1.37 \\
\hline & $(0.94)$ & $(0.56)$ & $(1.17)$ & $(0.37)$ & $(0.54)$ & $(0.58)$ \\
\hline \multirow[t]{2}{*}{ Average cropped land } & 0.86 & 1.19 & 0.87 & 0.79 & 0.85 & 1.37 \\
\hline & $(0.91)$ & $(0.87)$ & $(1.19)$ & $(0.35)$ & $(0.37)$ & $(0.97)$ \\
\hline \multirow[t]{2}{*}{ Average land size under bean } & 0.39 & 0.44 & 0.26 & 0.19 & 0.55 & 0.55 \\
\hline & $(0.39)$ & $(0.41)$ & $(0.34)$ & $(0.11)$ & $(0.40)$ & $(0.45)$ \\
\hline \multicolumn{7}{|l|}{ Land ownership (\%) } \\
\hline Woman & 18.6 & 4.35 & 18.18 & 0.00 & 19.05 & 6.25 \\
\hline Man & 46.51 & 86.96 & 54.55 & 100.00 & 38.1 & 81.25 \\
\hline Man and woman & 6.98 & 2.17 & 9.09 & 0.00 & 4.76 & 3.13 \\
\hline Other & 27.91 & 6.52 & 18.18 & 0.00 & 38.1 & 9.38 \\
\hline
\end{tabular}


The analysis in Table 1 also shows that landholdings for men and women were 1.06 and 1.23 acres, respectively, with almost equal sizes for men and women in the two counties pooled results indicate that women allocated up to $81 \%$ ( 0.86 acres) of the total land to crop production compared to $97 \%$ (1.19 acres) allocated by men. This finding reveals possible gender disparities in control over production resources at household levels. County disaggregated results revealed women in Embu allocated 0.87 acres, while men allocated 0.79 acres to crop production. However, while men in Nakuru allocated the entire (1.37 acres) land to crop production, women had $77 \%$ ( 0.85 acres) of land to crops. Nevertheless, the area of land allocated to bean production by men and women in Nakuru was equal (0.55 acres) In Embu, men and women allocated 0.44 acres and women 0.39 acres to bean production. Most men (87\%) and women (47\%) respondents reported that men owned land, suggesting possible disparities in women's access and control over land.

\subsection{Varieties Planted Differentiated by Gender and County}

First, the paper compared men's and women's preferences for common bean varieties. The results presented in Table 2 are bean varieties grown by participants in the study disaggregated by season and county. Wairimu, local varieties, Mwitemania, Nyota, Kifam, Angaza, and KAT B1, were the most grown varieties in both Counties. Warimu, Mwitemania, Kifam, and landraces (other local varieties and old varieties), and Nyota, Angaza, and KAT B1 are improved varieties with Nyota and Angaza biofortified with iron and zinc. Multiple varieties are usually grown for different reasons, including income generation, household food security, or adaptation to changing climatic conditions. Our study found out that more women grew landraces than men in Embu County. This may be attributed to seed availability at household level in form of saved seed and in local markets, as well as affordable local prices. In addition, women farmers may not find it viable to invest in the highly priced improved bean varieties, especially if the returns are not worth the investment cost. While Nyota is grown across the two counties, Angaza and Faida were only grown in Embu. Nyota's popularity among farmers in both Counties can be attributed to its superior biotic and abiotic traits, like drought-tolerance, early maturing, high yielding, and fast cooking [32]. The acceptance of this variety is attributed to promotional activities such as field days and demonstrations conducted by NARS and CIAT since the release of biofortified bean varieties in 2017.

Table 2. Varieties planted disaggregated by sex of the farmers and county.

\begin{tabular}{|c|c|c|c|c|c|c|}
\hline \multirow[b]{2}{*}{ Variety } & \multicolumn{2}{|c|}{ Pooled } & \multicolumn{2}{|c|}{ Embu } & \multicolumn{2}{|c|}{ Nakuru } \\
\hline & Woman & Men & Woman & Men & Woman & Men \\
\hline Wairimu & 21.69 & 25.56 & & & 38.3 & 34.85 \\
\hline Local & 19.28 & 6.67 & 44.44 & 25.00 & & \\
\hline Mwitamania & 15.66 & 25.56 & 2.78 & 8.33 & 25.53 & 31.82 \\
\hline Nyota & 12.05 & 7.78 & 19.44 & 20.83 & 6.38 & 3.03 \\
\hline Kifam & 12.05 & 11.11 & & & 21.28 & 15.15 \\
\hline Angaza & 3.61 & 5.56 & 8.33 & 20.83 & & \\
\hline Faida & 2.41 & 1.11 & 5.56 & 4.17 & & \\
\hline Mama Safi & 2.41 & 3.33 & 5.56 & 12.5 & & \\
\hline Duriandu & 2.41 & & 5.56 & & & \\
\hline Rose coco & 1.20 & 1.11 & 2.78 & & & 1.52 \\
\hline KAT B1 & 3.61 & 4.44 & 2.78 & 4.17 & 4.26 & 4.55 \\
\hline Red bean & 1.20 & & 2.78 & 4.17 & & \\
\hline Noe & 1.20 & 1.11 & & & 2.13 & 1.52 \\
\hline Mukura & 1.20 & 2.22 & & & 2.13 & 3.03 \\
\hline Gituru & & 1.11 & & & & 1.52 \\
\hline Canadian wonder & & 1.11 & & & & 1.52 \\
\hline Mexican & & 1.11 & & & & 1.52 \\
\hline
\end{tabular}


There is no universal pattern of gendered adoption: in some areas, women plant more improved varieties than men; in others, the reverse is true. While higher proportions of men than women in Embu reported that they planted Nyota, women in Nakuru, who said that they planted Nyota was twice the men's proportions (Table 2). Additionally, the proportion of male farmers who planted Angaza was more than twice the proportion of women, while the proportions of men and women who planted Faida were almost equal. Men and women farmers in Embu planted the same bean varieties. In contrast, the varieties planted in Nakuru differed depending on the gender of the respondents. The proportion of women who planted Nyota was twice those of men. Furthermore, the proportions of men in Nakuru that planted Wairimu, Mwitamania, and Kifam were lower than their female counterparts. We see that men and women do have different rates of adoption, depending on location.

\subsection{Varietal Preferences Differentiated by Gender and County}

Furthermore, when participants evaluated bean lines in the trials, they were asked to select and rank the best varieties they preferred and state the reasons for their preferences. The analysis results presented in Table 3 indicate that men's and women's variety preferences differed across the two counties. Combined results suggest that more men $(50 \%)$ than women $(32 \%)$ preferred Nyota to other varieties. Equal proportions-nearly $24 \%$ of both men and women across the two sites preferred Angaza because the leaves fall off, making harvesting manageable and less labor-intensive. In contrast, more women than men preferred local variety and Mama Safi, possibly because they are adapted to local conditions and seed is readily available and affordable. Nonetheless, men and women farmers preferred the same varieties Embu. However, there were differences in varietal preferences between men and women in Nakuru. Whereas $48 \%$ and $40 \%$ of the women preferred Nyota and Angaza, about $61 \%$ and $26 \%$ of men preferred the same varieties, respectively. The proportion (11\%) of women in Nakuru who preferred Mwitemania was more than twice the proportion of men (Table 3).

Table 3. Proportions (\%) of farmer preferences of bean varieties in Embu and Nakuru disaggregated by gender of the respondents.

\begin{tabular}{cccccccccc}
\hline & \multicolumn{3}{c}{ Pooled } & \multicolumn{3}{c}{ Embu } & \multicolumn{3}{c}{ Nakuru } \\
\cline { 2 - 10 } & $\mathbf{N}$ & Women & Men & N & Women & Men & N & Women & Men \\
\hline Faida & 4 & 1.40 & 4.40 & 1 & 2.20 & 0.00 & 3 & 0.00 & 6.50 \\
Mwitemania & 14 & 9.70 & 10.30 & 9 & 8.90 & 22.70 & 5 & 11.10 & 4.30 \\
Wairimu & 1 & 0.00 & 1.50 & & & & 1 & 0.00 & 2.20 \\
Nyota & 57 & 31.90 & 50.00 & 16 & 22.20 & 27.30 & 41 & 48.10 & 60.90 \\
KAT B1 & 3 & 1.40 & 2.90 & 3 & 2.20 & 9.10 & & & \\
Local & 14 & 16.70 & 2.90 & 14 & 26.70 & 9.10 & & & \\
Angaza & 33 & 23.60 & 23.50 & 10 & 13.30 & 18.20 & 23 & 40.70 & 26.10 \\
Mama Safi & 8 & 8.30 & 2.90 & 8 & 13.30 & 9.10 & & & \\
Duriandu & 1 & 1.40 & 0.00 & 1 & 2.20 & 0.00 & & & \\
Red bean & 1 & 0.00 & 1.50 & 1 & 0.00 & 4.50 & & & \\
Katune & 1 & 1.40 & 0.00 & 1 & 2.20 & 0.00 & & & \\
Raila & 1 & 1.40 & 0.00 & 1 & 2.20 & 0.00 & & & \\
Gachuma & 1 & 1.40 & 0.00 & 1 & 2.20 & 0.00 & & & \\
Loni & 1 & 1.40 & 0.00 & 1 & 2.20 & 0.00 & & & \\
N & 140 & 72 & 68 & 67 & 45 & 22 & & & \\
\hline
\end{tabular}

Women preferred Mwitemania because of its high-yielding trait (Table 4). Various studies have also reported high yields as one of the most important traits influencing the adoption of new crop varieties in Kenya and Ethiopia [33,34]. Nearly $8 \%$ of the farmers reported that besides high yields, they preferred Mwitemania because it is early maturing, resistant to pests and diseases, marketable, and affordable. Other important 
traits for women's preference for Mwitemania was because it is early maturing $(7 \%)$, seed availability $(7 \%)$, palatable $(7 \%)$, and fast cooking $(7 \%)$.

Table 4. Reasons for farmers' preferences of the selected bean varieties disaggregated by gender and county.

\begin{tabular}{|c|c|c|c|c|c|c|c|}
\hline & & \multicolumn{2}{|c|}{ Pooled } & \multicolumn{2}{|c|}{ Embu } & \multicolumn{2}{|c|}{ Nakuru } \\
\hline & & Women & Men & Women & Men & Women & Men \\
\hline \multirow[t]{8}{*}{ Mwitamania } & Early maturity ${ }^{a}$ & 7.10 & 8.30 & 8.30 & 11.10 & & \\
\hline & Resistant to pest and diseases ${ }^{a}$ & 0.00 & 8.30 & & & 0.00 & 33.30 \\
\hline & Marketable ${ }^{a}$ & 0.00 & 8.30 & 0.00 & 11.10 & & \\
\hline & High yielding & 71.40 & 50.00 & 58.30 & 44.40 & 100.00 & 66.70 \\
\hline & Seed availability & 7.10 & 0.00 & 8.30 & 0.00 & & \\
\hline & Palatable & 7.10 & 16.70 & 16.70 & 22.20 & & \\
\hline & Fast cooking & 7.10 & 0.00 & 8.30 & 0.00 & & \\
\hline & Affordable & 0.00 & 8.30 & 0.00 & 11.10 & & \\
\hline \multirow[t]{11}{*}{ Nyota } & Early maturity ${ }^{a}$ & 7.70 & 3.80 & 9.10 & 8.30 & 5.30 & 2.50 \\
\hline & Resistant to pest and diseases ${ }^{a}$ & 5.10 & 3.80 & 0.00 & 8.30 & 10.50 & 2.50 \\
\hline & Nutritious ${ }^{a}$ & 0.00 & 1.90 & & & 0.00 & 2.50 \\
\hline & Marketable $^{\mathrm{a}}$ & 5.10 & 7.70 & 4.50 & 33.30 & 5.30 & 0.00 \\
\hline & Upright and firm & 5.10 & 0.00 & 4.50 & 0.00 & 5.30 & 0.00 \\
\hline & Labor reduction/less leaves $^{a}$ & 0.00 & 1.90 & & & 0.00 & 2.50 \\
\hline & High yielding & 66.70 & 73.10 & 59.10 & 16.70 & 73.70 & 90.00 \\
\hline & Palatable & 0.00 & 5.80 & 0.00 & 25.00 & & \\
\hline & Fast cooking & 5.10 & 1.90 & 13.60 & 8.30 & & \\
\hline & Low flatulence & 2.60 & 0.00 & 4.50 & 0.00 & & \\
\hline & Always grown it & 2.60 & 0.00 & 4.50 & 0.00 & & \\
\hline \multirow[t]{10}{*}{ Angaza } & Early maturity ${ }^{a}$ & 3.80 & 6.70 & 0.00 & 25.00 & 7.10 & 0.00 \\
\hline & Resistant to pest and diseases ${ }^{\text {a }}$ & 3.80 & 6.70 & & & 7.10 & 9.10 \\
\hline & Marketable $^{\mathrm{a}}$ & 3.80 & 6.70 & 8.30 & 25.00 & & \\
\hline & Upright and firm & 7.70 & 0.00 & 8.30 & 0.00 & 7.10 & 0.00 \\
\hline & Labor reduction/less leaves ${ }^{a}$ & 0.00 & 3.30 & & & 0.00 & 4.50 \\
\hline & High yielding & 69.20 & 70.00 & 58.30 & 25.00 & 78.60 & 86.40 \\
\hline & Palatable & 3.80 & 3.30 & 8.30 & 12.50 & & \\
\hline & Fast cooking & 3.80 & 3.30 & 8.30 & 12.50 & & \\
\hline & Low flatulence & 3.80 & 0.00 & 8.30 & 0.00 & & \\
\hline & & 26 & 30 & 12 & 8 & 14 & 22 \\
\hline
\end{tabular}

Note: ${ }^{\text {a }}$ denotes that the trait is preferred together with a high yielding trait of the bean variety selected by the farmers.

Furthermore, the results in Table 4 shows that besides high yields, women in Embu preferred Mwitemania because of seed availability, fast cooking. At the same time, men cited marketability and affordability as the main reasons for their preferences for Mwitemania. Women prioritize early maturing traits over marketability traits because they tend to be more concerned about household food security [35] and, therefore, more likely to adopt early maturing bean varieties to provide food to the household at all times. For example, Siri et al. [36] found that women bean farmers in Cameroon preferred early maturing varieties because of the need to smooth food consumption between two harvests. This study also confirms Bruno et al. [37] findings, who reported that women appeared to be disinterested in some varieties' marketability compared to men. In Nakuru, while $68 \%$ of men farmers preferred Mwitemania because it is high yielding, they also considered it because of its resistance to pests and diseases. Women in Embu preferred landraces because they were easily accessible.

The analysis in Table 5 also shows that more women in male-headed households (40\%) selected and ranked Nyota higher than other varieties. Similarly, male respondents (59\%) in male-headed households selected and ranked Nyota higher than they ranked other bean varieties in the trial. Coincidentally, equal proportions-29\% - of men in female-headed households selected and ranked Nyota, Angaza, and Mwitemania as the best varieties in the trial. Interestingly, the percentages of women in female-headed households that selected and ranked Mwitemania, Nyota, and Angaza as the best in the trial were lower than those 
from male-headed households. Additionally, there were differences in the selection and ranking of varieties between male and female married participants. Higher proportions $(56 \%)$ of married men selected and ranked Nyota as the best in the trial than their women $(37 \%)$ counterparts because they were possibly aware of the potential contribution of the variety to the financial needs of households. The selection and ranking of the varieties were the same for single, separated or divorced, and widowed respondents.

Table 5. Bean varieties selected and ranked as best in the trial disaggregated by gender and sociodemographic characteristics of the respondents.

\begin{tabular}{|c|c|c|c|c|c|c|c|c|}
\hline \multirow[b]{2}{*}{ Variable } & \multicolumn{2}{|c|}{ Local } & \multicolumn{2}{|c|}{ Mwitemania } & \multicolumn{2}{|c|}{ Nyota } & \multicolumn{2}{|c|}{ Angaza } \\
\hline & Women & Men & Women & Men & Women & Men & Women & Men \\
\hline \multicolumn{9}{|l|}{ Education level (\%) } \\
\hline No formal education & 100.00 & & & & & & & \\
\hline Primary & 17.24 & 0.00 & 10.34 & 6.45 & 48.28 & 61.29 & 24.14 & 32.26 \\
\hline Secondary & 30.77 & 8.70 & 19.23 & 17.39 & 23.08 & 52.17 & 26.92 & 21.74 \\
\hline Tertiary & 0.00 & 25.00 & 12.50 & 25.00 & 50.00 & 25.00 & 37.50 & 25.00 \\
\hline University & 33.33 & & & & & 66.67 & & \\
\hline \multicolumn{9}{|l|}{ Age of respondent (\%) } \\
\hline Less than 35 years & 22.22 & 11.11 & 22.22 & 22.22 & 22.22 & 44.44 & 33.33 & 22.22 \\
\hline 35 years and older & 23.21 & 5.77 & 12.50 & 9.62 & 39.29 & 57.69 & 25.00 & 26.92 \\
\hline \multicolumn{9}{|l|}{ Sex of household head (\%) } \\
\hline Male & 10.00 & 3.70 & 20.00 & 11.11 & 40.00 & 59.26 & 30.00 & 25.93 \\
\hline Female & 25.93 & 28.57 & 12.96 & 14.29 & 35.19 & 28.57 & 25.93 & 28.57 \\
\hline \multicolumn{9}{|l|}{ Land ownership (\%) } \\
\hline Woman & 25.00 & 0.00 & 8.33 & 0.00 & 33.33 & 50.00 & 33.33 & 50.00 \\
\hline Man & 22.22 & 7.55 & 14.81 & 13.21 & 44.44 & 52.83 & 18.52 & 26.42 \\
\hline Man and woman & 40.00 & 0.00 & 20.00 & 0.00 & 20.00 & 100 & 20.00 & 0.00 \\
\hline Other & 14.29 & 0.00 & 14.29 & 0.00 & 35.71 & 100 & 35.71 & 0.00 \\
\hline \multicolumn{9}{|l|}{ Marital status (\%) } \\
\hline Married & 23.53 & 5.26 & 11.76 & 12.28 & 37.25 & 56.14 & 27.45 & 26.32 \\
\hline Single & 50.00 & 50.00 & & & 25.00 & 50.00 & 25 & 0.00 \\
\hline Separated/divorced & & & 50.00 & 0.00 & 50.00 & 0.00 & 0.00 & 50.00 \\
\hline Widowed & 12.50 & & 25.00 & & & 37.50 & & 25.00 \\
\hline
\end{tabular}

The reasons for farmers' preferences for Nyota were almost the same for men and women across and within the counties as shown in Table 4. The proportion of women farmers who indicated that Nyota is early maturing was twice the proportion of men. While women in Embu preferred Nyota because of low flatulence, firm and upright stem, fasting cooking, men in the same county reported that they preferred the variety because of its marketability, resistance to pests and diseases, and palatability. The proportions of women farmers in Nakuru that preferred Nyota for its early maturity and resistance to pests and diseases were higher than those of their male counterparts. In contrast to women in Embu, more women in Nakuru preferred Nyota because it is marketable and has an upright and firm stem. On the other hand, Nakuru men indicated that they preferred Nyota due to its low labor requirement. Thus, marketability is a trait was more preferred traits to men, but although women were less focused on market traits, they also prefer crops that they can sell and spend the income on household needs.

Reasons for preferring Angaza differed depending on the gender of the farmers both within and across the two counties. Besides high yields, equal proportions, $4 \%$, of women across the two counties preferred Angaza because it is early maturing, has low flatulence, is resistant to pests and diseases, and is marketable (Table 4). In contrast, $7 \%$ of men-twice the women's proportions-reported that Angaza was early maturing, resistant to pests and diseases, and marketable. While one-quarter of men in Embu reported marketability, only eight percent of women reported marketability as the reason for preferring Angaza. The result shows that men and women are both market-oriented in their preferences for Angaza. Furthermore, more than half (58\%) of women in Embu indicated that Angaza was high 
yielding; only one-quarter of men explained they preferred it because of high yields. In contrast, more women than men in Nakuru preferred Angaza because it is early maturing.

\subsection{Gender Gaps in Common Bean Production}

Access and Purchase of Common Bean Seeds

The results in Table 6 show that most of the farmers across the two counties, regardless of their gender, reported that they used "own saved" seed in the March-July and OctoberDecember cropping season. While pooled results show that more women than men obtained seed from agro-dealers, more men than women in Nakuru and more women than men in Embu obtained seed from agrovets. Thus, there is a need for agro-dealers to target both men and women farmers as potential buyers in the two counties. Further disaggregation of the results indicated that while more women $(11.5 \%)$ than men $(7 \%)$ in Embu bought seeds from agro-dealers, more men (12.5\%) than women (5\%) in Nakuru accessed seed from agro-dealers. The results confirm a critical observation made by Islam et al. [38] that farmers are increasingly adopting newly released varieties when they are easily accessible in agro-vets close to them.

Table 6. Sources of bean seed and financing disaggregated by gender and county.

\begin{tabular}{|c|c|c|c|c|c|c|c|}
\hline & \multirow[b]{2}{*}{ Response } & \multicolumn{2}{|c|}{ Pooled } & \multicolumn{2}{|c|}{ Embu } & \multicolumn{2}{|c|}{ Nakuru } \\
\hline & & Women & Men & Women & Men & Women & Men \\
\hline \multirow[t]{4}{*}{ Seed Source } & Own seed & 65.96 & 71.74 & 69.23 & 71.43 & 61.9 & 71.88 \\
\hline & Grain market & 2.13 & 2.17 & 19.23 & 21.43 & 28.57 & 12.50 \\
\hline & Agrovet & 23.40 & 15.22 & 11.54 & 7.14 & 4.76 & 12.50 \\
\hline & Fellow farmer/relative & 8.51 & 10.87 & & & 4.76 & 3.13 \\
\hline \multicolumn{8}{|c|}{ Who provides money } \\
\hline & Man & 20.00 & 91.3 & 15.79 & 90.91 & 27.27 & 91.67 \\
\hline & Woman & 66.67 & 4.35 & 73.68 & & 54.55 & \\
\hline & Both & 13.33 & & 10.53 & & 18.18 & 8.33 \\
\hline & Other & & 4.35 & & 9.09 & & \\
\hline
\end{tabular}

Additionally, an equal percentage, $2 \%$, of women and men reported that they obtained seed from local grain markets from pooled data. However, the proportion (21\%) of men in Embu who bought seed from the grain market was higher than that of women (19\%). In contrast, more women (29\%) than men (13\%) in Nakuru obtained seed from the local grain market. Seed sourced from the market might be quality declared seeds or certified seed sold as grain after one season of cultivation, as reported in the yellow bean study conducted in Tanzania [39]. The finding is also consistent with [40], who reported that up to $90 \%$ of bean seed in Sub-Saharan Africa is sourced locally from informal channels. These results reveal low access to and use of improved bean seed in the two counties. Interestingly, women and men in both counties indicated that they bought seeds themselves instead of their spouses. While $91 \%$ of men indicated that they financed the purchase of seed, $67 \%$ of women across the two counties reported that they used their own money to buy the seed.

Who buys the seed depends on or is influenced by decision-making processes within households. When the decision is jointly made, the seed variety purchased will be agreed upon by the man and woman or household head and spouse. However, when the men are the final decision-makers with respect to agricultural production decisions or finance seed purchase, they may buy whatever variety they want, disregarding what women instructed them to get even if women control or manage bean production. However, men may buy the varieties requested by women when women provide the cash. Therefore, the one who buys the seed may influence choices and preferences for bean variety and traits and eventual adoption. In addition, if the man and women are implicated in bean production on a family farm, the man is likely to buy the seed varieties he prefers and not necessarily what the women want if they have different preferences. Moreover, if a woman is purchasing the 
seed, she is likely to buy what the man wants and some varieties that meet the food and nutritional needs of the households.

\subsection{Effect of Three Main Preferred Varieties on Selected Gender Aspects}

Table 7 presents respondents' perceptions of the trade-offs of biofortified released varieties. The results shows that more women in Nakuru (54.5\%) reported that Nyota increased drudgery for them compared to their male counterparts. Both men and women agreed that Angaza and Mwitemania did not increase drudgery for them across both counties. Men might not consider drudgery an issue because women provide labour for drying, threshing, winnowing, and other post-harvesting activities. On another note, women in Nakuru and men in Embu agreed that Nyota displaced women from other activities, unlike men from Nakuru and Women from Embu. Men in Nakuru said Angaza displaces women from other activities than women in Nakuru and men and women in Embu. Women in Embu said Mwitemania displaces women from other activities, unlike men in Embu and women and men in Nakuru. The introduction of improved varieties is mostly accompanied by good agronomic practices such as planting in rows, weeding twice, spraying, applying fertilizers, increasing women's workload, and displacing them from other household and reproductive activities. In all counties, men and women farmers agreed that Nyota, Angaza, and Mwitemania increase or maintain employment for women across the counties as more than $70 \%$ of women grow common bean in these counties and contribute to on-farm labor.

Table 7. Gender-related dynamics in bean production.

\begin{tabular}{|c|c|c|c|c|c|c|}
\hline & & & Nakuru & & Embu & \\
\hline Parameter & Variety & & Men & Women & Men & Women \\
\hline \multirow[t]{3}{*}{ Does selected variety increase drudgery } & Nyota & Yes $(\%)$ & 33.33 & 54.55 & 0.00 & 11.11 \\
\hline & Angaza & Yes $(\%)$ & 16.67 & 22.22 & 0.00 & 0.00 \\
\hline & Mwitemania & Yes (\%) & 0.00 & 0.00 & 0.00 & 0.00 \\
\hline \multirow{3}{*}{$\begin{array}{l}\text { Does variety displace women from other } \\
\text { activities }\end{array}$} & Nyota & Yes $(\%)$ & 33.33 & 63.64 & 50.00 & 12.50 \\
\hline & Angaza & Yes $(\%)$ & 50 & 44.44 & 0.00 & 0.00 \\
\hline & Mwitemania & Yes $(\%)$ & 0.00 & 0.00 & 0.00 & 50.00 \\
\hline \multirow{3}{*}{$\begin{array}{l}\text { Does variety increase or maintain } \\
\text { employment for women }\end{array}$} & Nyota & Yes $(\%)$ & 79.17 & 72.73 & 100.00 & 100.00 \\
\hline & Angaza & Yes (\%) & 100.00 & 88.89 & 100.00 & 100.00 \\
\hline & Mwitemania & Yes (\%) & 100.00 & 100.00 & 100.00 & 100.00 \\
\hline \multirow{3}{*}{$\begin{array}{l}\text { Does variety need added input women } \\
\text { cannot access? }\end{array}$} & Nyota & Yes $(\%)$ & 95.83 & 81.82 & 50.00 & 44.44 \\
\hline & Angaza & Yes $(\%)$ & 100.00 & 66.67 & 25.00 & 25.00 \\
\hline & Mwitemania & Yes (\%) & 100.00 & 0.00 & 66.67 & 50.00 \\
\hline
\end{tabular}

Interestingly, even though Nyota, Angaza, and Mwitemania increased drudgery and displaced women from other activities, it also provided employment options resulting in tradeoffs. Men and women across the county agree that growing Nyota, Angaza, and Mwitemania needed additional input that women cannot access in most cases. In addition, it has been documented that most smallholder farmers are risk-averse, meaning they are less likely to invest in additional inputs and technology adoption [41]. This may present a challenge for extension officers promoting varieties with high input requirements if no in-kind or financial support is provided. For these reasons, there is a need for public-private partnerships to encourage adoption and access to affordable inputs, especially for women. To solve tradeoff, the adoption of other technologies to reduce drudgery like a motorized sprayer, planter and thresher might be relevant.

Table 8 presents the association between socio-economic characteristics and gender gaps created by the best traits preferred by men and women. Higher educational attainment (with secondary education and above) among women farmers was associated with 
women indicating that the best traits maintained or increased women's employment. The result implies that education raised the awareness of the importance of selected traits in creating employment for women at the farm-level and other points in the bean value chain. More women from female-headed households than male-headed households also indicated that preferred traits increased employment for women. Female-headship possibly increased autonomy for women to select varieties that would improve their employment in agriculture. In contrast, there were no differences in men perceptions of the implications of selected varieties depending on their socio-economic characteristics (education and headship) regarding preferred traits increasing or maintaining employment for women.

Table 8. Association between socio-economic factors and gender gaps created by men and women preferred traits.

\begin{tabular}{ccc}
\hline & Mean $/ \%$ & Mean $\%$ \\
\hline Maintain or increase employment for women & & \\
\hline Education level & & 92.86 \\
\hline Primary & 92.31 & 72.73 \\
\hline Secondary and above & 100 & 81.48 \\
\hline Headship & 50 & 100 \\
\hline Male & 93.33 & \\
\hline Female & & 1.70 \\
\hline Displace women from usual activities & 0.91 \\
\hline Total land area & 1.05 \\
\hline Yes & 0.72 \\
\hline No & \\
\hline Require additional input & 1.40 \\
\hline Total land area & 0.67 \\
\hline Yes & 0.83 \\
\hline No & 0.82 \\
\hline
\end{tabular}

The total land area owned by households explained differences in men's responses about best varieties displacing women from their usual activities and requiring additional input in bean production. Men respondents indicate that the best traits would increase women needing support in acquiring farm inputs such as fertilizer, seed, and labor, resulting in the displacement of women from their usual domestic, farm, and social activities if they had access to large land sizes. Men respondents appear to have acknowledged that women face significant challenges in bean production, including limited access to land and inputs such as fertilizer, labor, and seed. The best traits selected by male farmers would imply that women have to invest more, including time and resources, in bean production resulting in tradeoffs in terms of time spent on other farms or domestic activities.

\section{Discussion}

The cultural construction of gender roles, socio-economic conditions, and agro-ecological conditions are among the challenges women face in agriculture. Breeding is one of the options for enabling women to overcome the constraints. Breeders are essential in developing crop varieties that adapt to agro-ecological and socio-economic conditions. However, the varieties need to be responsive to the needs and preferences of different groups of farmers and other value chain actors. In other words, the varietal traits need to be sensitive to the needs of women and other vulnerable groups, depending on the environment they operate in and socio-economic conditions such as access to assets, labor, and production goals [11]. This study demonstrated men's and women's preferences of bean varieties and identified possible socio- 
economic conditions that influence these preferences. Furthermore, the study also highlighted possible gender gaps that may accentuate or attenuate already existing gender gaps.

First, there were gender differences in varieties planted by men and women in the two counties. Women in Embu tended to plant more local varieties than men. At the same time, more men than women planted improved bean varieties (Mwitemania, Nyota, and Angaza) than women. This finding suggests gender gaps in access or adoption of improved varieties persist, which underlines results reported in previous studies that have indicated that women's propensity to adopt new technology is low compared to men [42,43]. Men are more likely to grow commercial crops and have the financial capacity to pay for inputs. They earn more off farm than women, and at home they use the land over which they have control to grow commercial crops rather than contribute to household food security, using the money they have acquired off farm to buy inputs necessary to increase productivity of improved varieties. To boost household food security, breeders need to concentrate on varieties that yield well under low input intensification. Extension workers need to concentrate on improved soil fertility based on farm-produced soil additives and practices such contour bunds, companion planting, manure, compost, and legume intercrops.

Women farmers also planted diverse bean varieties than men, indicating that diversification is key as they seek to meet multiple goals for bean production. The analysis also revealed that both men and women emphasized market traits, but women were more interested in food security traits such as early maturing and high yielding. In addition, seed accessibility and availability had implications on the choice or adoption of the bean varieties. The implication to the breeding program is that the trait characteristic is gendered and should be the cornerstone when developing new varieties before they are released, as they will determine success in terms of adoption or achievement of breeding goals.

Second, the novelty of this study was a redefined PVS tool—a gender-responsive PVS tool that incorporated sociodemographic backgrounds of men and women. We explained how socio-economic factors played a role in selecting and ranking the three most preferred bean varieties in the trial. Differences in terms of age of the respondents as a possible explanation for varied varietal preferences between men and women could be attributed to men and women having diverse experiences in bean production. Furthermore, the results suggest that women's land ownership did not matter much in influencing their selection of biofortified improved bean varieties compared to women in households where men were landowners. Even so, joint ownership of land by man woman was more associated with women preference to local varieties. Therefore, land ownership could either accentuate or attenuate gender varietal trait preferences.

Third, Ref. [11] posited that adoption decisions are highly gendered; therefore, plant breeding programs should help achieve the gains relevant to men and women amid their socio-economic conditions. However, breeders may get the gendered preferences in the product profile right. Still, adoption or continued use of the products would not be guaranteed because of the unexpected implications of the traits on men and women. For instance, high-yielding varieties may increase drudgery for women, increase additional input, which is costly, lower women's control over benefits from the crop, or displace them from their usual activities. As indicated in the study, despite being preferred because it is high yielding, Nyota was reported to increase drudgery for women in Nakuru. Therefore, drudgery is a crucial element to consider when introducing a new variety, as it could determine adoption or dis-adoption. Since Nyota is an already released variety, there is an opportunity to develop post-harvest mechanization technology like threshers and planters to reduce drudgery. Mechanization technology would not only reduce drudgery but create economic opportunities for women and youths [44]. The women in Nakuru who mentioned that Nyota increased drudgery was because of the changes in practices promoted alongside the improved varieties. Women are expected to shift from broadcasting to planting in lines, use more fertilizers, and increase the number of times for weeding, thus increasing their triple burden. This is not to say other varieties do not increase drudgery for women, but the opinions are context-specific to the resources and time that women have 
available to them. Therefore, the downside of newly released varieties via their implication on women needs to be addressed for adoption and continued use of bean varieties.

Furthermore, sociodemographic characteristics such as education, household headship, and land size underlined the differences in the association between trait preferences and gender gaps by men and women. While higher education and female household headship were related with women indicating that preferred traits increase or maintain employment for women, men with larger landholding reported that best varieties would displace women from their usual activities and require additional inputs. The finding indicates that there are tradeoffs involved that need to be considered in breeding priorities. In some cases, creating a product that meets these preferences might not be possible. Still, the introduction of a gender-responsive technology like bean thresher or planter can solve the problem of drudgery, and engagement with private sector partners can also fill the inputs needs if they integrate strategies to reach the last mile farmers who are primarily women.

\section{Conclusions and Breeding Implications}

The common theme that has emerged from this study is that varietal and trait preferences differ by gender, with women have a greater range of trait preferences while men are more focused on market traits. Women preferred agronomic, post-harvesting, processing, and food use traits, while men preferred market traits such grain colour, shape, size and marketability Second, socio-economic conditions also play a crucial role in underlining gendered varietal and trait preferences, with education, age of farmers, household headship, and land ownership being the most important. The third finding is that Nyota, despite its attractive traits to both men and women, displaces women from their usual activities, increases drudgery, and requires additional input for women. The upside of Nyota, Mwitemania, and Angaza was that it increased or maintained employment for women. These are mixed implications of improved biofortified bean varieties, signifying possible tradeoffs when farmers decide to adopt these varieties.

The results have implications for future breeding programs and possible interventions. Breeding is expensive and meeting all farmers' preferences might sometimes not be possible. However, understanding men's and women farmers' needs would provide information to guide breeders in meeting both farmers' needs. In line with available resources, having a gender lens in any product profile design will reduce the cost of carrying out an extensive gender-responsive PVS later. Policymakers also need to invent ways of empowering women while addressing the issue of land use rights. Researchers need to assess these varieties' preferences along the whole value chain so that breeding becomes a value chain activity and not focused only on farmers' subset but meets other clients' needs. To enhance the new varieties' adoption, more attention should be paid towards developing varieties that appeal to women, looking at salient gender issues regarding labor, women empowerment, employment, and reducing drudgery. Striking a balance, albeit difficult, calls for public-private stakeholder engagements when developing breeding pipelines.

Author Contributions: Conceptualization, E.B.N., D.K. and E.K.; Formal analysis, C.K.L. and O.C.A.; Funding acquisition, E.B.N. and D.K.; Investigation, E.B.N.; Methodology, E.B.N., C.K.L., O.C.A., D.K. and E.K.; Project administration, D.K.; Supervision, D.K. and E.K.; Visualization, E.B.N.; Writingoriginal draft, E.B.N., C.K.L. and O.C.A.; Writing-review \& editing, E.B.N., C.K.L., O.C.A., D.K. and E.K. All authors have read and agreed to the published version of the manuscript.

Funding: Global Affairs Canada under the Improving Bean Production and Marketing supported this research in Africa (IBPMA) project and the Swiss Agency for Development and Cooperation. Bill and Melinda Gates Foundation funded the publication of this work under the Tropical Legume III (TLIII) and Accelerated varietal improvement and seed delivery of legumes and cereals in Africa (AVISA) projects under the auspices of the CGIAR-Research Program on Grain Legumes and Dryland Cereals (CRP-GLDC).

Institutional Review Board Statement: This study's ethical review and approval were waived since it was conducted by a government entity. 
Informed Consent Statement: Informed consent was obtained from all subjects involved in the study.

Data Availability Statement: Available on request.

Acknowledgments: We appreciate the support of all farmers and extension agents who made the participatory varietal selection session a success. We would like to acknowledge the support of KALRO during this study.

Conflicts of Interest: The authors declare no conflict of interest.

\section{References}

1. Fraval, S.; Hammond, J.; Bogard, J.R.; Ng'endo, M.; van Etten, J.; Herrero, M.; van Wijk, M.T. Food access deficiencies in sub-Saharan Africa: Prevalence and implications for agricultural interventions. Front. Sustain. Food Syst. 2019, 3, 1-13. [CrossRef]

2. Bicaba, Z.; Brixiová, Z.; Ncube, M. Can extreme poverty in Sub-Saharan Africa be eliminated by 2030? J. Afr. Dev. 2017, 19, 93-110.

3. Gattinger, A.; Jawtusch, J.; Müller, A.; Mäder, P. No-till Agriculture-a Climate Smart Solution? MISEREOR: Aachen, Germany, 2011. Available online: https:// orgprints.org/id/eprint/20302/1/MISEREOR_no_till.pdf (accessed on 25 November 2021).

4. Nyamadzawo, G.; Nyamugafata, P.; Wuta, M.; Nyamangara, J.; Chikowo, R. Infiltration and runoff losses under fallowing and conservation agriculture practices on contrasting soils, Zimbabwe. Water SA 2012, 38, 233-240. [CrossRef]

5. Zingore, S.; Mutegi, J.; Agesa, B.; Tamene, L.; Kihara, J. Soil degradation in sub-Saharan Africa and crop production options for soil rehabilitation. Better Crop. 2015, 99, 24-26.

6. Giller, K.E. The food security conundrum of sub-Saharan Africa. Glob. Food Secur. 2020, 26, 100431. [CrossRef]

7. Kruseman, G.; Mottaleb, K.A.; Tesfaye, K.; Bairagi, S.; Robertson, R.; Mandiaye, D.; Prager, S. Rural transformation and the future of cereal-based agri-food systems. Glob. Food Secur. 2020, 26, 100441. [CrossRef]

8. Smith, V.; Wesseler, J.H.; Zilberman, D. New plant breeding technologies: An assessment of the political economy of the regulatory environment and implications for sustainability. Sustainability 2021, 13, 3687. [CrossRef]

9. Eriksson, D.; Akoroda, M.; Azmach, G.; Labuschagne, M.; Mahungu, N.; Ortiz, R. Measuring the impact of plant breeding on sub-Saharan African staple crops. Outlook Agric. 2018, 47, 163-180. [CrossRef]

10. Weltzien, E.; Rattunde, F.; Christinck, A.; Isaacs, K.; Ashby, J. Gender and farmer preferences for varietal traits: Evidence and issues for crop improvement. Plant Breed. Rev. 2019, 43, 243-278.

11. Christinck, A.; Weltzien, E.; Rattunde, F.; Ashby, J.A. Gender Differentiation of Farmer Preferences for Varietal Traits in Crop Improvement: Evidence and Issues. 2017. Available online: https:/ / hdl.handle.net/10947/4660 (accessed on 25 November 2021).

12. Gender and Breeding Initiative. Plant Breeders Could Let Women Farmers Guide Them. 2018. Available online: http://www.rtb. cgiar.org/gender-breeding-initiative/news-and-opinions/news/plant-breeders-could-let-women-farmers-guide-them/ (accessed on 25 November 2021).

13. Katungi, E.; Aseete, P.; Mukankusi, C.; Nkalubo, S. Towards a More Gender-Responsive Bean Breeding Program: Lessons from East Africa. In State of the Knowledge for Gender in Breeding: Case Studies for Practitioners; Tufan, H.A., Grando, S., Meola, C., Eds.; Working Paper No. 3. CGIAR Gender and Breeding Initiative; International Potato Center (CIP): Lima, Peru, 2018 ; pp. 23-43. Available online: http:/ / cgspace.cgiar.org/handle/10568/92819 (accessed on 25 November 2021).

14. Burridge, J.D.; Findeis, J.L.; Jochua, C.N.; Miguel, M.A.; Mubichi-Kut, F.M.; Quinhentos, M.L.; Xerinda, S.A.; Lynch, J.P. A case study on the efficacy of root phenotypic selection for edaphic stress tolerance in low-input agriculture: Common bean breeding in Mozambique. Field Crop. Res. 2019, 244, 107612. [CrossRef]

15. Lynam, J. Plant Breeding in Sub-Saharan Africa in an Era of Donor Dependence. IDS Bull. 2011, 42, 36-47. [CrossRef]

16. Sumberg, J.; Gilbert, E.; Blackie, M. Income Diversity, Technology Choice and Agricultural Research Policy in Sub-Saharan Africa. Dev. Policy Rev. 2004, 22, 131-146. [CrossRef]

17. Minot, N.; Smale, M.; Eicher, C.K.; Jayne, T.; Kling, J.; Horna, D.; Myers, R. (Eds.) Seed Development Programs in Sub-Saharan Africa: A Review of Experiences; IFPRI: Washington, DC, USA, 2007.

18. Walker, T.; Alene, A.; Ndjeunga, J.; Labarta, R.; Yigezu, Y.; Diagne, A.; Pandey, S. Measuring the Effectiveness of Crop Improvement Research in Sub-Saharan Africa from the Perspectives of Varietal Output, Adoption, and Change: 20 Crops, 30 Countries, and 1150 Cultivars in Farmers' Fields. Synthesis Report for Objectives 1; CGIAR Independent Science and Partnership Council: Italy, Rome, 2014.

19. Kolech, S.A.; De Jong, W.; Perry, K.; Halseth, D.; Mengistu, F. Participatory variety selection: A tool to understand farmers' potato variety selection criteria. Open Agric. 2017, 2, 453-463. [CrossRef]

20. Sperling, L.; Loevinsohn, M.E.; Ntabomvura, B. Rethinking the farmer's role in plant breeding: Local bean experts and on-station selection in Rwanda. Exp. Agric. 1993, 29, 509-519. [CrossRef]

21. Vom Brocke, K.; Trouche, G.; Weltzien, E.; Barro-Kondombo, C.P.; Gozé, E.; Chantereau, J. Participatory variety development for sorghum in Burkina Faso: Farmers' selection and farmers' criteria. Field Crop. Res. 2010, 119, 183-194. [CrossRef]

22. Witcombe, J.; Joshi, A. Farmer Participatory Approaches for Varietal Breeding and Selection and Linkages to the Formal Seed Sector. Proceeding of the Workshop on Participatory Plant Breeding, Wageningen, The Netherlands, 26-29 July 1995; Eyzaguirre, P., Iwanaga, M., Eds.; Participatory Plant Breeding. IPGRI: Rome, Italy, 1996; pp. 57-65.

23. Assefa, T.; Sperling, L.; Dagne, B.; Argaw, W.; Tessema, D.; Beebe, S. Participatory plant breeding with traders and farmers for white pea bean in Ethiopia. J. Agric. Educ. Ext. 2014, 20, 497-512. [CrossRef] 
24. Asfaw, A.; Almekinders, C.J.; Blair, M.W.; Struik, P.C. Participatory approach in common bean (Phaseolus vulgaris L.) breeding for drought tolerance for southern Ethiopia. Plant Breed. 2012, 131, 125-134. [CrossRef]

25. Weltzien, E.; Rattunde, F.; Sidibé, M.; Vom Brocke, K.; Diallo, A.; Haussmann, B.; Diallo, B.; Nebie, B.; Toure, A.; Christinck, A. Long-term collaboration between farmers' organizations and plant breeding programmes: Sorghum and pearl millet in West Africa. In Farmers and Plant Breeding: Current Approaches and Perspectives; Westengen, O.T., Winge, T., Eds.; Routledge: Abingdon, UK; New York, NY, USA, 2020; pp. 29-48.

26. Tegbaru, A.; Menkir, A.; Baco, M.N.; Idrisou, L.; Sissoko, D.; Eyitayo, A.O.; Tahirou, A. Addressing gendered varietal and trait preferences in West African maize. World Dev. Perspect. 2020, 20, 1-9. [CrossRef]

27. Ashby, J.; Polar, V. The Implications of Gender for Modern Approaches to Crop Improvement and Plant Breeding. In Gender, Agriculture and Agrarian Transformation; Sachs, C., Ed.; Routledge: London, UK, 2019; pp. 11-34.

28. Ashby, J.A.; Polar, V. User guide to the G+ product profile query tool (G+PP). In CGIAR Research Program on Roots, Tubers and Bananas, User Guide 2021-2; International Potato Center: Lima, Peru, 2021. Available online: https://hdl.handle.net/10568/113167 (accessed on 25 November 2021).

29. Orr, A.; Cox, C.M.; Ru, Y.; Ashby, J. Gender and Social Targeting in Plant Breeding. Lima (Peru), CGIAR Gender and Breeding Initiative. GBI Working Paper. No. 1. 2018. Available online: www.rtb.cgiar.org/gender-breeding-initiative (accessed on 25 November 2021).

30. Ashby, J. Relevance, Adoption, and Impact: Why Gender Matters in Breeding. In State of the Knowledge for Gender in Breeding: Case Studies for Practitioners; Working Paper No. 3; CGIAR Gender and Breeding Initiative; Tufan, H.A., Grando, S., Meola, C., Eds.; International Potato Center (CIP): Lima, Peru, 2018; pp. 11-21. Available online: http:/ / oar.icrisat.org/10678/ (accessed on 25 November 2021).

31. Teeken, B.; Olaosebikan, O.; Haleegoah, J.; Oladejo, E.; Madu, T.; Bello, A.; Tufan, H.A. Cassava Trait Preferences of Men and Women Farmers in Nigeria: Implications for Breeding. Econ. Bot. 2018, 72, 263-277. [CrossRef]

32. Dalberg. Commercialisation Assessment: High Iron Beans in Tanzania. 2019. Available online: https://nutritionconnect.org/ sites/default/files/2020-01/191213_Tanzania_Iron\%20Beans_Report_vFINAL.pdf (accessed on 25 November 2021).

33. Karimi, R.; Nair, R.; Ledesma, D.; Mutisya, D.; Muthoni, L. Performance and participatory evaluation of green gram genotypes in the semi-arid environments of Eastern Kenya. East Afr. Agric. For. J. 2019, 83, 119-136. [CrossRef]

34. Tarekegne, W.; Mekbib, F.; Dessalegn, Y. Performance and Participatory Variety Evaluation of Finger Millet [Eleusine coracana (L.) Gaertn] Varieties in West Gojam Zone, Northwest Ethiopia. East Afr. J. Sci. 2019, 13, 27-38.

35. Ibidunni, A.S.; Ufua, D.E.; Okorie, U.E.; Kehinde, B.E. Labour productivity in agricultural sector of Sub-Sahara Africa (2010-2017). Afr. J. Econ. Manag. Stud. 2019, 11, 207-232. [CrossRef]

36. Siri, B.N.; Tchouamo, I.R.; Nchanji, E.B. Gender analysis of farmers' perception of improved haricot bean (Phaseolus vulgaris L.) varieties in the West Region of Cameroon. Int. J. Agric. Policy Res. 2020, 8, 107-115.

37. Bruno, A.; Katungi, E.; Stanley, N.T.; Clare, M.; Maxwell, M.G.; Paul, G.; Richard, E. Participatory farmers' selection of common bean varieties (Phaseolus vulgaris L.) under different production constraints. Plant Breed. 2018, 137, 283-289. [CrossRef]

38. Pieter, P.; Donovan, J. Sticking with the old seed: Input value chains and the challenges to deliver genetic gains to smallholder maize farmers. Outlook Agric. 2020, 49, 39-49.

39. Birachi, E.; Mutua, M.; Mukankusi, C.; Templer, N.; Sperling, L.; Onyango, L.; Kalemera, S.; Buruchara, R.; Dey, B.; Rubyogo, J.C. Yellow Bean Corridor Seed Grain Trade Potential. 2020. Available online: https://www.agrilinks.org/post/yellow-beancorridor-seed-grain-trade-potential (accessed on 25 November 2021).

40. McGuire, S.; Sperling, L. Seed systems smallholder farmers use. Food Secur. 2016, 8, 179-195. [CrossRef]

41. Das, B.; Van Deventer, F.; Wessels, A.; Mudenda, G.; Key, J.; Ristanovic, D. Role and Challenges of the Private Seed Sector in Developing and Disseminating Climate-Smart Crop Varieties in Eastern and Southern Africa; BT-The Climate-Smart Agriculture Papers: Investigating the Business of a Productive, Resilient and Low Emission F; Rosenstock, T.S., Nowak, A., Girvetz, E., Eds.; Springer: Cham, Switzerland, 2019. [CrossRef]

42. Fisher, M.; Carr, E.R. The influence of gendered roles and responsibilities on the adoption of technologies that mitigate drought risk: The case of drought-tolerant maize seed in eastern Uganda. Glob. Environ. Chang. 2015, 35, 82-92. [CrossRef]

43. Wambua, S.; Birachi, E.; Gichangi, A.; Kavoi, J.; Njuki, J.; Mutua, M.; Karanja, D. Influence of productive resources on bean production in male and female-headed households in selected bean corridors of Kenya. Agric. Food Secur. 2018, 7, 1-8. [CrossRef]

44. FAO. The Future of Food and Agriculture: Trends and Challenges; Food and Agriculture Organization of the United Nations: Rome, Italy, 2017; Available online: http: / / www.fao.org/3/a-i6583e.pdf (accessed on 25 November 2021). 